\title{
Triple Helix in the Poverty Reduction Policy Based on Community Empowerment in Semarang City
}

\author{
Amni Zarkasyi Rahman ${ }^{1}$ and Diyah Novitasari ${ }^{2}$ \\ ${ }^{1}$ Department of Public Administration, Faculty of Social and Political Science Universitas Diponegoro, Semarang - Indonesia
}

\begin{abstract}
The policy of poverty reduction based on empowerment issued into Local Regulation of Semarang City No. 12 in 2016 will be hard to implement without stakeholders. It needs a relationship of university-industry-government so that policy poverty reduction can be run well. This relationship can be seen from the role of Tri Dharma of Universities and CSR from various companies in community development and community empowerment. The important thing is synchronization between development policy, Road Map community service by the university, and CSR strategic plan in order to avoid overlapping in the implementation of community development programs. Role identification of the triple helix relationship needs to be reviewed so that University-industry-government has a proportionate and effective function.
\end{abstract}

Keywords: Triple Helix; Empowerment; CSR.

\section{Introduction}

Poverty reduction is one of the most pressing issues in every policy in Indonesia. This is due to many citizens who have assumed that reforms in developing countries prioritize social development in overcoming poverty [1]. Of course, a lot of policy products in an effort to reduce the poverty rate, starting with the National Program of Community Empowerment (PNPM Mandiri) to various "magic cards" such as Smart Indonesia Card (KIP); Healthy Indonesia Card (KIS) and Prosperous Family Card (KKS), which used to be known as Social Protection Card (KPS). However, the program has not been able to reduce poverty significantly until now because the program has not been able to increase the value of assets owned by the impoverished.

One of the causes of poverty is lack of knowledge about asset management [2]. Therefore, it is necessary to empower communities in the management of their assets. The assets are any forms of potential that is owned to improve the family economy, for example, are capital, skills, and building. This form of empowerment will succeed if supported by the synergism between university-industry-government in the concept of triple helix [3].

\section{Methodology}

Empowerment as the transformation of society should be able to understand thoroughly through the scientific thoughts as problems significantly [4]. Therefore, this study used descriptive qualitative method aimed to describe clearly on focus issues of research [5], the pattern of the relationship triple Helix in the implementation of poverty reduction based on empowerment in Semarang. Furthermore, the data was collected via the study of the literature such as good scientific literature print, online media, and the news that is in local and national portal official news. The first part of this study describes how the pattern of the relationship triple Helix University-industrygovernment in general. The next section describes Gerbang Hebat as a real manifestation program of poverty reduction based on empowerment in Semarang, included on how the program implemented and what activities are included. Then, on the last part will be explained how the pattern of the relationship triple Helix University-industry-government in poverty reduction based on empowerment in Semarang.

\section{Discussion}

\subsection{Triple Helix and Poverty Reduction}

Development is inseparable from the inception of the ideas, creativity, and new science supporting the development process. One part of the country's development process is poverty reduction. The success of development in relation to poverty reduction certainly inseparable from the role of stakeholders. The economic development of an innovative and 
sustainable country not only comes from a strong Government, the University, and the business world but rather to how mutualism interaction entwined to achieve a strategic goal [6].

Ideas, creativity, and science that will significantly affect to poverty reduction efforts in the triple helix concept. The Triple helix itself is a driving system of community assets based on skills, creativity, and science with a proportionate role of each actor.

The mutualism relationship in Triple Helix can occur beginning with the government's request to the university or the industry's demand for the university that each wants the university to participate and contribute to the strategic plan. Once the strategic plan is drawn up by the University, it is the turn of the Government or industry to provide facilitation in the implementation framework of the community empowerment program. Ideally, the emerging presence of hybrid organizations [3] as part of the implementation of the triple helix concept (Fig. 1).

Fig. 1. The Triple Helix Model

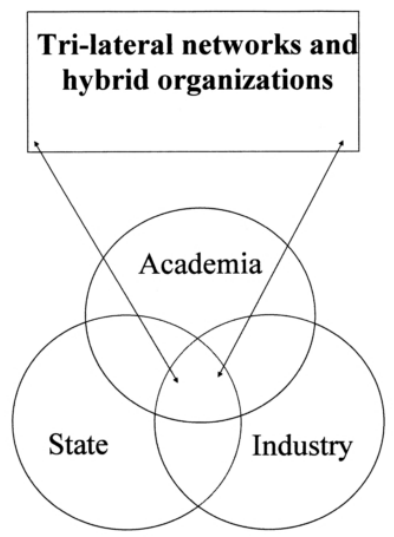

According to the Fig. 1, there are hybrid organizations in the form of new institutions that are built by the three of the stakeholders (IndustryUniversity-Government) that can accommodate the community as subject and object of community empowerment. This institutional is certainly part of the implementation of the previously drafted strategic plan using the approach of Rapid Rural Appraisal (RRA) and Participatory Rural Appraisal (PRA) ${ }^{7}$. RRA and PRA are used so that the established institutions really "needs" rather than "wishes" of the community. Therefore, a separate research is required in the form of Social Mapping conducted by the University to obtain a map of actors (stakeholders) and network of relationships between actors consisting of individuals, groups, and organizations; description of the social position and the role of social actors in community life; degree of strength (power) analysis and actors interest; mapping of actors (stakeholders) and the network of relationships between actors that consists of individuals, groups, and organizations; a description of sustainable livelihood potentials that include human resources potential, natural resource potential, social capital, financial capital, condition of public infrastructure; analysis of the community necessity to support sustainable livelihoods; description types vulnerability and vulnerable groups; description of social issues; as well as the recommendations of the program community development (CD).

\subsection{Gerbang Hebat as a Real Poverty Education Effort Manifestation}

Gerbang Hebat is an abbreviation of the Joint Movement for Unemployment and Poverty Reduction through Economic Harmonization, Education, Ecosystems and the ethos of community sharing. This program will run under four scenarios in four clusters i.e. poverty reduction based on social assistance, community empowerment, facilitation of Micro Small Medium Enterprises (UMKM), and the expansion of pro-people programs [8]. The purpose of the Gerbang Hebat is an effort to accelerate poverty reduction in Semarang City by aligning City Government programs with existing stakeholders such as universities, banks, State-Owned Enterprises (BUMN), community leaders and entrepreneurs [9].

The realization of four clusters of the Gerbang Hebat is the e-warong Kube PKH (Joint Venture Group in the Hope Family Program which aims to channel aid to the poor not in cash but in the form of basic needs) as a manifestation of poverty reduction based on social assistance. E-warong spread across 61 points in every sub-district in Semarang City. In addition, there are Kampung Tematik programs that include poverty reduction efforts based on community empowerment, facilitation of MSMEs, and the pro-people expansion.

In the program of Kampung Tematik there are efforts undertaken to overcome the problems of fulfilling basic needs primarily on improving the quality of living environment of poor people and basic infrastructure of settlements, as well as improving the community economy through the development of Kampung Tematik based on kampong (village) potential and facilitation of MSMEs by developing handicrafts and eco-friendly home industries as a supporting product of Kampung Tematik's icon [10].

Kampung Tematik emerges a healthy environment. Green and clean environment lead to a pleasant society. It creates willingness to develop and maintain Kampung Tematik. Through a great benefits of Kampung Tematik, it needs an involvement form government to support Kampung Tematik.

Kampung Tematik has been implemented in all sub-districts in Semarang City with 2 villages as Kampung Tematik in each sub-district. Some examples of thematic villages (Kampung Tematik) in Semarang are Kuningan Village (Healthy and Children-friendly Village), Krapyak Village (Agro-village), Rejomulyo Village (Batik Village), Tambakrejo Village (village central of milkfish), and many more thematic villages. There are at least 15 universities and 15 companies giving Corporate Social Responsibility (CSR) who play an active role supporting the Gerbang Hebat through mentoring, coaching, and financing in the creation of Kampung Tematik [11]. 


\subsection{The Collaboration of University and Industry in Implementation of the Gerbang Hebat}

Academics provide an important role in the formulation of Community Empowerment Road Map that would be implemented within the framework of CSR programs. Not only in the formulation process, but academics also participate in mentoring the implementation of the CSR program. This is what will make the new entity hybrid organizations have competitiveness through the knowledge transfer that is done on an ongoing basis.

The real form of mentoring can be seen from the efforts of Universitas Diponegoro who perform one of Tri Dharma of Universities is the empowerment of the village society in Semarang City. This empowerment program is carried out in a sustainable manner, in accordance with the respective source of funding. As funding source of the program can be derived from Ministry of Research, Technology and Higher Education; internal funds of the university; and cooperation funds with industry, or government/private institutions. Opportunity for collaboration between University-Industry-Government can be seen from the existence of Partnership Program scheme between University-CSR or University- Government-CSR [12]. This scheme emphasizes the synergy that is built in the University-Industry-Government relationship manifested in the form of cooperation of expertise, integration, togetherness in the implementation of the program and the funding contribution (Fig. 2).

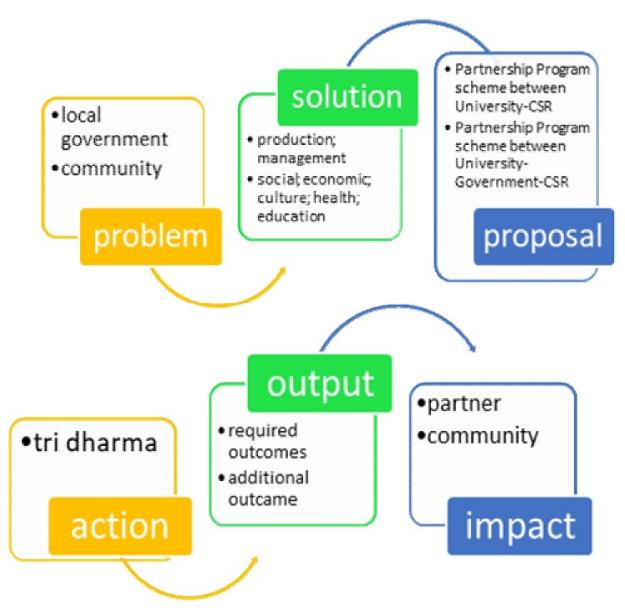

Figure 2. Scheme Process of Proposal Preparation and Implementation

Various types of CSR activities that have been undertaken by companies in Semarang City such as free health screening, mass circumcision, cataract surgery, and counseling about healthy living (health), coaching and granting soft loan for merchants and MSMEs (economic), granting scholarships (education), as well as construction of public facilities such as public toilets and drains (infrastructure). However, many companies are still carrying out his CSR independently and not integrated with government programs so that there are still many CSR programs that are not right on target and not in accordance with the needs of the Community [13].

The example of integrated collaboration with the involvement of University-Industry-Government is the mentoring of the implementation of CSR cooperation between Universitas Diponegoro-PT. Pertamina TBBM Semarang Group-Semarang City Government which implemented in Kelurahan Kemijen. The collaboration is part of the implementation of CSR program which is based on the Community Development Strategic Plan of Kemijen Village, Semarang Timur Sub-district in 2016-2020. The programs implemented include the Business Incubator Program and Eco-friendly Waste Management Program.

\section{Conclusion}

The collaboration among University-IndustryGovernment is required for poverty reduction programs to have a positive impact as expected. However, many of the company's CSR programs are conducted independently and not integrated into government's programs so there are duplications of some poverty reduction programs. Therefore, the Semarang City Government as an authority having the legality to form policy on poverty reduction needs to formulate policies that regulate the coordination of government and stakeholders, especially the coordination of government, universities and companies in the implementation of CSR in order to support the success of the Gerbang Hebat program as a poverty reduction strategy in Semarang City.

\section{References}

1. M. S. Grindle, Good Enough Governance: Poverty Reduction and Reform in Developing Countries, Governance vol. 17 (4) pp 525-548 (2004)

2. C. O. N. Moser, The Asset Vulnerability Framework: Reassessing Urban Poverty Reduction Strategies, World Development vol. 26 (1) pp 1-19 (1998)

3. H. Etzkowitz and L. Leydesdorff, The dynamics of innovation: from National Systems and "Mode 2" to a Triple Helix of university-industrygovernment relations, Research Policy, 29(2), pp 109-123 (2000)

4. J. W. Creswell, Research Design: Qualitative, Quantitative, and Mixed Methods Approaches, SAGE Publications, Inc., California (2014)

5. C. P. Sianipar, \& A. A. G. Yudoko, Community empowerment through appropriate technology: sustaining the sustainable development, Procedia Environmental Sciences, pp 1007-1016 (2013) 
6. J. N. Kimatu, Evolution of Strategic Interactions from The Triple to Quad Helix Innovation Models for Sustainable Development in the Era of Globalization, World Development volume 5 (1) pp 16 (2016)

7. T. Dunn, Learning to Use RRA and PRA to Improve The Activities If Two Landcare Groups in Australia (1993)

8. Tjok, Hendi Launching "Gerbang Hebat" Entaskan Kemiskinan dan Penangguran Retrieved from https://jatengekspos.com (2017)

9. Semarang P. K., Tujuan Gerbang Hebat. Retrieved from http://gerbanghebat.semarangkota.go.id

10. Semarang P. K., Kampung Tematik. Retrieved from http://gerbanghebat.semarangkota.go.id
11. N. Chamin, Gandeng 15 Kampus, Sukseskan Kampung Hebal, Retrieved from https://radarsemarang.com (2016)

12. O. K. Radjasa, Panduan Pelaksanaan Penelitian \& Pengabdian kepada Masyarakat di Perguruan Tinggi Edisi XI Tahun 2017, Kementerian Riset, Teknilogi, dan Perguruan Tinggi, Jakarta (2017)

13. S. Ma'rif, A. Sugiri, N. Waskitaningsih, and R. N. Hayati, Kajian Kebijakan Corporate Social Responsibility (CSR) Riptek, Jakarta (2013) 